Article

\title{
The Rise of Technocratic Leadership in the 1990s in the People's Republic of China
}

\author{
Rongrong Lin
}

Research Center of CPC Rules and Regulations, Institute of Urban Governance, Shenzhen University, 518060 Shenzhen, China; E-Mail: rlin@szu.edu.cn

Submitted: 5 June 2020 | Accepted: 15 September 2020 | Published: 25 November 2020

\begin{abstract}
The transformation of China's political elite provides important insights into the nation's political metamorphosis and the changes in cadre selection criteria. The current literature explains the composition of Chinese political elites by referencing cross-sectional biographic data and describing how the revolutionary veterans stepped down and were replaced by the technocrats who emerged in the 1980s and 1990s. However, explanations for the rise of the technocrats have largely been limited to socioeconomic factors. By analyzing the longitudinal data of Chinese provincial leaders during the period of 1990-2013, this article shows the rise of technocrats in Chinese politics in the 1990s but also provides an explanation for it from the perspectives of individuals' career paths and the contemporaneous political and policy landscapes. These explanations were drawn from analyses of the expansion of higher education and faculty restructuring in the 1950s, graduate job assignments, the recruitment and promotion of young and middle-aged cadres, and the cadre policy known as the Four Modernizations of the early 1980s. This article presents the interactions among individuals' career opportunities, group composition characteristics, and socioeconomic and macropolitical dynamics. It also reveals how the Chinese Communist Party legitimizes its ruling power and maintains state capacity and political order through elite recruitment.
\end{abstract}

\section{Keywords}

China; education reform; elites; Four Modernizations; technocrats

\section{Issue}

This article is part of the issue "Leadership and Political Change in Asia-Pacific" edited by David Hudson (University of Birmingham, UK), Nicolas Lemay-Hébert (Australian National University, Australia), Claire Mcloughlin (University of Birmingham, UK) and Chris Roche (La Trobe University, Australia).

(C) 2020 by the author; licensee Cogitatio (Lisbon, Portugal). This article is licensed under a Creative Commons Attribution 4.0 International License (CC BY).

\section{Introduction}

More so than at any time since the founding of the People's Republic of China in 1949, there has been an upsurge of theoretical and practical interest in the study of Chinese leaders. Because this is an important factor in China's elite politics, institutional changes, and socioeconomic development, many specialists have rushed to ask the question of who is running China using empirical data to present a comprehensive picture of leadership transformation. Scholars have provided substantive insight into the prevailing norms and prudential rules of leadership selection, particularly in reform-era China. They have observed the emergence of technocrats in Chinese politics since the early 1980s and full-fledged technocratic leadership in the 1990s (Andreas, 2009; Lee, 1991; Li \& White, 1988, 1990, 1998). In the existing literature, this profound leadership transition is primarily explained by the increasing demand for highly educated candidates with technocratic expertise who were meant to guide China's rapid industrialization and economicmodernization projects.

This explanation, however, is far from complete and leaves open more fundamental questions for empirical investigation. For example, are technocrats a growing presence in the Chinese political power structure? How were technocrats recruited into the party and state hierarchies? What accounts for the rise of the technocrats? Did it signal that expertise was favored over Redness in political competitions for authority positions? If the 
socioeconomic explanation for elite transformation was complete, then why did not technocrats come to the fore in the 1950s and the 1960s when the state's policies were geared towards industrialization and the national building agenda relied heavily on technical experts? (Xu, 2001, p. 67)

This article presents answers to all of these questions by analyzing empirical data about Chinese provincial leaders during the period of 1990-2013. This advances our knowledge of China's technocrats in three ways. First, this article will analyze the rise and fall of technocrats and career bureaucrats in provincial politics from a historical perspective. Second, this article will, for the first time, interpret the rise of the technocrats by investigating the opportunities at different time points throughout the lives of the provincial leaders studied here. It will seek to explain how technocrats obtained their education, professional work experience, and political status. It will further examine the interactions among individual career opportunities, elite group composition, and broader institutional frameworks. Finally, the current literature generally evaluates the nature and competitive advantages of technocrats by studying their technocratic orientation, educational backgrounds, and career patterns. This article will take a step further and analyze the role of political capital of the technocratic elite through party membership and occupational experience as party workers.

The first section of this article presents a review of the research literature pertaining to Chinese leadership transformation, particularly the technocracy thesis. The second section briefly introduces the biographic dataset of provincial leaders and the operational definition and measurement of technocrats. The third section describes the historical changes leading up to the unbalanced proportion of technocrats and career bureaucrats among provincial leaders. In the fourth section, the rise of the technocrats in the 1990s is explained by reviewing both the biographies of individual leaders as well as the socioeconomic and macropolitical dynamics. After summarizing the study's major findings, this article will conclude by discussing the historical necessity for technocratic leadership in China since the early 1980s.

\section{Chinese Leadership Transformation and the Emergence of Technocratic Leadership}

The question of who is running China used to be answered by consulting rumors and hearsay about supreme leaders or rising political stars during leadership transitions. Sensibly, the analytical focus has turned to a general and quantitative account of biographic characteristics of cadres at varying levels ranging from the central, provincial, municipal, county, and grass-roots (Bo, 2002, 2008; Feng, 2010; Goodman, 1980; Landry, 2003; Lee, 1983; Li, 2002; Li \& Bachman, 1989; Li \& White, 1988, 1998, 2003; Lin, 2012; Zang, 1991, 1993). The growing consensus in this flourishing area of scholarly inquiry is that Chinese leadership possesses three essential features: male dominance, Han dominance, and increasing education. Meanwhile, a wave of China scholars is now paying special attention to the technocratic movement in Chinese leadership. However, there is a debate between those scholars who view Chinese politics as a technocracy and those who view it as a political technocracy.

The rise of China's technocrats is often traced to the 12th Party Congress of 1982 (Li, 2002; Li \& White, 1988, $1990,1998)$. After that, the ruling elite was a group of technically trained leaders with professional job experience, such as industrial managers, economic planners, and engineers (Li, 2002, pp. 25-28; Li \& White, 1998, pp. 235-236). Sharing a similar technocratic identity and a pragmatic orientation (Li \& White, 1988, pp. 395-396), they maintained leadership unity and stability along with mutual recognition (Li \& White, 1998, p. 234). However, in parallel to this observation, other scholars have specifically rejected the idea of dominance by the technocrats. Instead, they point out the cooperative coexistence of technocrats and career bureaucrats; neither group has absolute authority because they share political power (Lee, 1983; Zang, 1991, 1993, 1999). As Xiaowei Zang (1993, p. 801) put it:

The career bureaucrats need the technocrats for their advice and expertise, and thus need to share power with them. The technocrats need to cooperate with the career bureaucrats in order to climb up the political hierarchy that has been controlled by the latter.

In this respect, leadership formation is conceived as a political technocracy instead of just a technocracy (Zang, 1991, p. 123).

What is not debated is the emergence of a technocratic elite who were meant to change how power is legitimized in China and to negotiate the nation's massive political and socioeconomic changes (Li \& White, 1988, pp. 395-396, 1990, pp. 12-13, 1998, p. 234). This is seen as a fundamental response to the demands of modernization, economic prosperity, and technological development (Zang, 1993, pp. 789-790). In other words, as argued by Cheng Li and David Bachman (1989, p. 89):

Under the impact of an accelerating worldwide scientific and technological revolution, technical expertise should be a basic credential for leadership and a fundamental reason for popular support. According to these leaders, modern society is so complex that only experts can estimate the implications of a decision.

This scholarly divergence has appeared primarily because of the relative weakness of the technocratic elites and the relative strengths of career bureaucrats. For example, there is a reasonable amount of skepticism that technocrats could effectively cope with complex sociopolitical issues that are different from technical issues (Li \& Bachman, 1989, p. 90). As Cheng Li and Lynn 
White discuss (1990, pp. 20-21):

Social and economic problems sometimes caused by new policies often occur more rapidly than the means technocrats can devise to deal with them. Their technical 'expertise' is probably even more important as a legitimacy to justify their rule than as a functional requisite of their leadership.

Career bureaucrats usually rise from the grassroots, step by step. They possess broad career experience and accumulate political and human capital in diversified functional divisions as well as in party and government organs. They are relatively advantaged in bureaucratic operations, specialized knowledge, and experience in governance. Generally, they have better people skills than technocrats who have technical jobs and only work with machines or other highly skilled people. Given these differences, it could be argued that career bureaucrats have co-opted technical professionals into the power center while hindering the rise of technocrats.

Cheng Li and Lynn White identify 1982 as the watershed year for technocratic leadership in China, when Li Peng, Hu Qili, Jiang Zemin, Wang Zhaoguo, Hu Jintao, and Wu Bangguo were elected as Central Committee (CC) members or alternate CC members (Li \& White, 1988, p. 380). Before 1982, the percentage of technocrat members of the 9th, 10th, and 11th CCs was only around $2 \%$. It increased to $17 \%$ in the 12 th CC and went up to $20 \%$ in the 13th CC. Based on this evidence, $\mathrm{Li}$ and White (1988) concluded there was an emerging technocratic leadership in China. Xiaowei Zang (1993, pp. 789-791), however, pointed out that the proportion of technocrats was too small to sustain Li and White's conclusion. Zang (1993) noted that technocrats accounted for $32.80 \%$ of the membership of the 14th CC, while career bureaucrats were $40.74 \%$. In another study, Zang (1991) observed 302 central government cadres; the percentages of technocrats and career bureaucrats were $23.18 \%$ and $47.02 \%$, respectively. Zang concluded that technocrats and career bureaucrats are two important political forces and, thus, the notion of political technocracy is a better fit for the composition of China's leadership. However, in the 15th CC, Li and White (1998) noted that at least $55.4 \%$ of full CC members were technocrats.

The empirical studies discussed above suffer from two limitations: missing data and problematic definitions of the term technocrat. Li and White (1998, p. 235) defined technocrats in terms of technocratic major, professional occupation, and leadership position. However, the classification of technocratic majors is ambiguous. For example, some empirical studies classify the academic fields of finance, economics, or management as technocratic majors along with engineering and the natural sciences; others do not. Furthermore, in most studies, the percentage of technocrats was calculated by considering technocratic major and leadership position only, regardless of professional occupation. The percentage of technocrats may be overestimated because some may have had a technocratic major but no professional work experience. The missing-data problem may have led to measurement errors. Specifically, information was unavailable for the academic majors of $39.24 \%$ of the cadres in Zang's investigation of bureaucrats in the central government, $36.1 \%$ of the members in Zang's study of the 14th CC, and $22.0 \%$ of the members in Li and White's study of the 15th CC (Li \& White, 1998; Zang, 1991, 1993).

\section{Methods and Data}

This article addresses two questions: (1) How the proportion of technocrats has evolved in provincial leadership, and (2) how they assumed political positions. The data was collected by capturing information about 1,891 provincial party secretaries, governors, deputy party secretaries, and vice governors from 1990 to 2013, representing $85.10 \%$ of all provincial leaders for the study period. Leadership biographies were drawn from diverse, authoritative sources, such as official government websites, the leadership databases of Xinhua Net, People.com.cn, Chinese Economics Net and the like. The leadership profiles were cross-checked against the Chinese Political Elite Database of National Chengchi University of Taiwan. To trace historical changes and individual leaders, a provincial leadership dataset was created with a personyear structure, recording who occupied what provincial leadership position in each province on a yearly basis. In this way, the dataset contains 9,814 life-history observations. Three sets of information were coded to trace provincial leaders' life course transitions from school to work. They include: (1) educational levels, academic majors, and the time of attaining educational qualifications; (2) party membership and the time of joining the Chinese Communist Party; and, (3) previous work experience in industry, engineering, economic management, the State-Owned Enterprises (SOE), and party work.

This study adopted $\mathrm{Li}$ and White's (1998, pp. 235-236) definition of technocrat and Zang's (1993, p. 788) definition of career bureaucrat. Career bureaucrat was defined as a state or party cadre without a technocratic major working in the party and government systems, mass organizations, the People's Liberation Army, or other agencies. Technocrat was defined by three dimensions: education, professional occupation, and leadership position. To avoid definitional ambiguities, some clarifications and refinements were made for the measurement details of technocrats. For example, the previous empirical studies did not distinguish between full-time and part-time college work and only captured individuals' highest educational attainments. The fact is that the number of college-educated provincial leaders has grown steadily year-to-year. Among them, the percentage majoring in the humanities and social sciences has increased significantly from 50\% in 2000 to $79.64 \%$ in 2012 (Lin, 2017). This trend was paralleled by a sharp 
rise in the percentage of provincial leaders obtaining part-time college education, up from $29.95 \%$ in 2000 to $79.11 \%$ in 2013 . However, measuring credentials in the form of the highest educational qualification achieved results in an underestimation of the number of technocrats. This study therefore focused only on full-time college education and traces the entire full-time educational histories. In addition, technocratic majors were limited to natural and applied sciences, such as physics, chemistry, biology, geology, mathematics, engineering, agriculture, and medical science.

In terms of professional career experience, this study adopted the measurement strategy of main career patterns used by Cheng Li and David Bachman (1989, p. 75) and Xiaowei Zang (1993, pp. 797-798), and studied the frequency and length of job experience. Unlike the previous empirical studies, specific work experience in industry, engineering, and economic management was considered. That is, those working in these specialized areas for ten years or longer were also regarded as potential technocrats. To summarize, for the purpose of operationalization, technocrat was defined as a person: (1) receiving a degree from a full-time college, or above, in a technocratic major and (2) having a main career pattern, or ten years' experience, in industry, engineering, or economic planning.

\section{Historical Changes in Technocrats and Career Bureaucrats}

Of the provincial leaders in the study period of 1990 to $2013,79.55 \%$ received a college education. As indicated in Table 1, among these college-educated leaders, $55.44 \%$ were trained in a technocratic major and $38.91 \%$ in the humanities and social sciences. Particularly, provin- cial leaders studying engineering constituted $38.22 \%$ of the total. The technically trained elites were a larger proportion of the 1990-2013 provincial leaders compared to those who studied the humanities and social sciences.

A technocratic major was only one of the factors analyzed for technocratic leadership. The next critical step was to classify and examine career patterns. Technocrats generally had career experience in industry, engineering, or economics. As shown in Table 2, only $15.77 \%$ of the elites were recruited into provincial leadership as professional specialists in industry, engineering, or economic planning. At the same time, a large number of career bureaucrats came to power, accounting for $64.32 \%$ of all provincial leaders. Party workers accounted for $52.45 \%$, whereas government administrators were only $8.63 \%$. To take insight into the tenures in industry, finance and engineering respectively, provincial leaders with 10 -year tenure or longer provide $21.98 \%$ in industry, $10.76 \%$ in finance and $0.92 \%$ in engineering. Taking both the main career patterns and job tenures in professional occupations together, $32.26 \%$ of provincial leaders worked as industrial managers, engineers, or economic planners.

After considering both technocratic majors and relevant career patterns, technocrats accounted for $20.13 \%$ of the 1990-2013 provincial leaders. Among these technocratic elites, $73.84 \%$ acquired professional titles, such as professor or engineer. From a historical point of view, there was a fluctuating increase in the percentage of technocrats, from $26.21 \%$ in 1990 to $32.79 \%$ in 1996 (Figure 1). From 1997 onward, however, the percentage of technocrats continuously declined from $32.54 \%$ in 1997 to $9.13 \%$ in 2013 . The fluctuating increase in technocrats was accompanied by a fluctuating decrease in career bureaucrats from 1990 to 1997. As illustrated in

Table 1. Academic majors of Chinese provincial leaders, 1990-2013.

\begin{tabular}{lrr}
\hline & Obs. & $\%$ \\
\hline Technocratic Major & & \\
Physics/Chemistry/Biology/Geology/Mathematics & 863 & 11.05 \\
$\quad$ Engineering & 2,984 & 38.22 \\
$\quad$ Agriculture & 364 & 4.66 \\
$\quad$ Medical Science & 117 & 1.50 \\
Subtotal & 4,328 & 55.44 \\
Humanities \& Social Sciences & & 2.69 \\
$\quad$ Philosophy & 210 & 12.10 \\
$\quad$ Economic/Finance & 945 & 7.47 \\
$\quad$ Legal Studies/Political Science & 9.73 \\
$\quad$ Education & 583 & 12.27 \\
$\quad$ Literature/Linguistics & 57 & 2.91 \\
$\quad$ History & 958 & 0.74 \\
Management & 227 & 38.91 \\
Subtotal & 58 & 5.65 \\
Unknown & 3,038 & 100.00 \\
Total & 441 & 7,807 \\
\hline
\end{tabular}

Source: Author's database. 
Table 2. Main career patterns of Chinese provincial leaders, 1990-2013.

\begin{tabular}{lrr}
\hline & Obs. & \% \\
\hline Party Work & 5,147 & 52.45 \\
Government Administration & 847 & 8.63 \\
Mass Organization & 251 & 2.56 \\
Military & 67 & 0.68 \\
$\quad$ Subtotal & 6,312 & 64.32 \\
Industry & 865 & 8.81 \\
Engineering & 90 & 0.92 \\
Economic/Finance & 593 & 6.04 \\
$\quad$ Subtotal & 1,548 & 15.77 \\
Education & 658 & 6.70 \\
Police/Court & 101 & 1.03 \\
Personnel/Organization & 144 & 1.47 \\
Resource/Environment & 364 & 3.71 \\
Propaganda/Media & 133 & 1.36 \\
Others & 5.64 \\
$\quad$ Total & 554 & 100.00 \\
\hline
\end{tabular}

Source: Author's database.

Figure 1, bureaucrats were at $34.46 \%$ in 1990 , with a small drop to $28.25 \%$ in 1993 . Thereafter, the percentage of career bureaucrats slightly rose to $30.25 \%$ in 1994 and then declined to $26.67 \%$ in 1996 and $26.68 \%$ in 1997. The small fluctuation over the period of 1990-1997 was followed by a consecutive increase from $29.07 \%$ in 1998 to $44.59 \%$ in 2007 . Thereafter, the percentage of career bureaucrats slowly reached its peak of $45.13 \%$ in 2010 and modestly decreased to $37.32 \%$ in 2013 .

By comparing technocrats and bureaucrats in provincial politics from 1990 to 2013, the percentage of career bureaucrats dramatically exceeded that of technocrats during the period of 1990-1991 and from 2000 onwards. The rise of technocratic leadership was discernible in

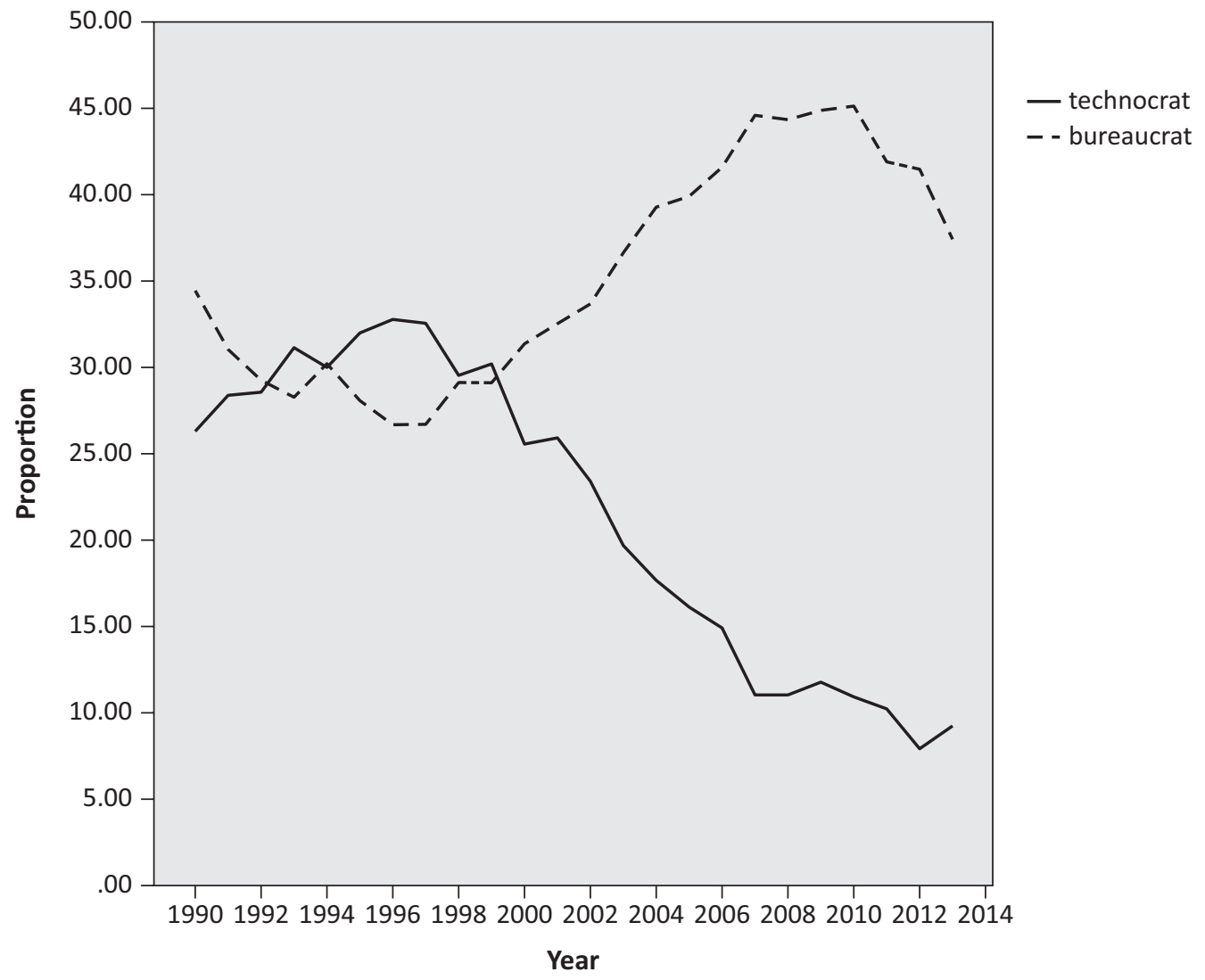

Figure 1. Technocrats and career bureaucrats in provincial leadership (1990-2013). 
the 1990s, particularly from 1992 to 1999 . Despite the high number of provincial leaders trained in science and engineering, the data suggests there was no technocratic dominance in reform China. In reality, the provincial elite transformation of the period 1990-2013 has turned away from technocratic leadership. It has alternatively moved toward a bureaucratic-technocracy characterized by the relative dominance by career bureaucrats since 2000 .

\section{Explaining the Rise of Technocrats in the 1990s}

How can the rise of technocratic leadership in the 1990s be explained? This question can be divided into three specific questions. First, where did the collegeeducated technical specialists with technocratic majors come from? Second, how did college-educated technical specialists acquire professional career experience? Third, how did technical specialists come to occupy political positions and become technocrats? The first two questions seek to understand how the party state nurtured a highly specialized and science-oriented labor force for industrialization and state building. The third question is meant to explain why this group of technical specialists were eventually turned into a pool of qualified candidates for political leadership after the introduction of the cadre policy of the Four Modernizations (ganbu sihua, 干部四化).

\subsection{Attending University: Educational Expansion and Faculty Restructuring}

Most of the technocrats in China's provincial leadership in the 1990s came from the birth cohorts of the 1930 s and the 1940 s, accounting for $29.88 \%$ and $65.46 \%$, respectively. Those from the same birth cohort were likely to have experienced the same major historical events and state policy shifts across their lives (Li, 2002, p. 6). Before the Cultural Revolution, $98.05 \%$ of the 1990s technocrats were admitted into university. Among them, a majority received their full-time college education between 1958 and 1965. The period of the mid-1950s through the mid-1960s was the first large-scale expansion of education in the People's Republic of China history. The Chinese Communist Party sought to fight illiteracy and to improve educational credentials in order to build the state. As early as 1953, the Cultural and Education Committee of the Central People's Government Administration Council placed primary emphasis on education, particularly higher education. According to 'the Decision on Education Work' (guanyu jiaoyu gongzuo de zhishi, 关于教育工作的指示) issued in September 1958, the Chinese Communist Party made every effort to achieve universal college education within 15 years and improve its quality for another 15 years.

Along with educational expansion, faculty restructuring took place in a broad range of universities in China. In June 1950, Zhou Enlai (1950, p. 19) stressed to the
National Higher Education Conference that restoring economic and social order created an urgent need for a specialized labor force. In November 1951, the National Conference for Deans of Engineering Faculties laid the groundwork for a far-reaching faculty restructuring. The goal of higher education was nurturing technical specialists so a reform plan for engineering faculties was proposed. The nationwide faculty restructuring was initiated in 1952. Its priority was training technical experts and teachers and developing specialized colleges for industrialization and economic development. After the faculty restructuring of 1953, the number of comprehensive universities decreased from 49 in 1949 to 14 in 1953. The number of engineering-oriented universities grew from 28 in 1949 to 38 and that of normal universities for teacher training grew from 12 to 33 . The percentage of science-and-engineering-oriented universities had two remarkable increases before the Cultural Revolution. The first increase occurred in 1952 when across-theboard faculty restructuring was launched. Science-andengineering-oriented universities accounted for $51 \%$ of the total universities all over China as compared to $38 \%$ in 1951. The second increase occurred in 1958 when the percentage of science-and-engineering-oriented universities increased from $49 \%$ in 1957 to $62 \%$. At the same time, the enrollment rate for these specialized universities grew from 54\% in 1949 to $64.5 \%$ in 1953. After 1960, it was over $70 \%$ every year and reached its height of $90.7 \%$ in 1969.

A vast majority of the 1990s technocrats attended university during the educational expansion and faculty restructuring of the 1950s. The academic majors they chose were in accord with the regime's overarching agenda for industrial and economic growth. For example, in order to strengthen national defense, promote economic development, and improve living standards, the First Five-Year Plan (1953-1957) proposed the policy of industrialization, particularly the development of heavy industry. The Second Five-Year Plan (1958-1962) continued the policy of heavy industry, particularly in the areas of metallurgy, machine production, petrochemicals, power generation, coal, construction materials, and the like. As for the academic majors of the 1990s technocrats, $39.96 \%$ studied mechanical engineering and $16.75 \%$ studied chemical engineering. Those majoring in steel and metallurgy, civil engineering, and aeronautics and astronautics accounted for $10.28 \%, 9.61 \%$, and $6.95 \%$, respectively. This empirical evidence supports the proposition that the academic majors preferred by technocrats echoed the context of China's industrialization and economic policies.

\subsection{From School to Work: The Evolving Graduate Job Allocation Plan}

In addition to the education received in the era of farranging educational reforms, technocrats experienced a particular type of transition from school to work and 
found their places in professional occupations. This question is related to their first job and their job tenure in professional occupations.

Looking at the 1990 s technocrats as a group, $94.01 \%$ received technocratic training from a full-time college education and a first job in the corresponding professional field. And, $80.59 \%$ of all technocrats embarked on their professional careers by occupying a highly technical job at an SOE. Only $4.47 \%$ assumed political positions in the party system or government hierarchies immediately after college graduation. A vast majority of technocrats with SOE job experience remained at the same SOEs or were transferred to different SOEs in the early- or mid1980s. The average SOE tenure was 16.15 years.

Facilitating this education to job match was the centralized graduate job placement plan which lasted from the 1950s through the 1980s and became prevalent in the 1960s and the 1970s. The essential pillar of the plan was the party state's rigid control over job assignments for graduates, and its final political decision on how and where to place skilled manpower. The important 'Decision on Reforming Length of Schooling' (guanyu gaige xuezhi de jueding, 关于改革学制的决定) released in August 1951 underlined the job placement plan of university graduates by government. In the process of state planning, universities and colleges reported the supply of prospective graduates. Work units reported their specific demands for labor to the overseeing departments. The overseeing departments transmitted the supply-and-demand information to the state planning department through the hierarchical structure. The state planning department subsequently developed a draft for the national manpower plan and gained the approval of the State Council. Following that, the approved plan was delivered from the top down to local departments and then to universities and work units. This process of job allocation under state planning left little room for graduates, tertiary universities, and work units to negotiate. In 1952, the plan adhered to the central government's allocations of labor to premier construction projects and to remote regions to aid the nation's industrialization and state-building strategies. The core value of the centralized graduate job allocation plan lay in efficiently extracting and mobilizing specialized human resources in the face of the daunting obstacles of socialist reconstruction tasks, economic hardship, and a desperate shortage of skilled labor in the early years of the People's Republic of China. It fostered job-worker matching by promoting matches between university courses and the requirements of particular jobs and by acquiring employment information on both the supply and demand sides. The central government also sought to enhance the geographical balance by deploying human resources to rural and remote regions (Agelasto, 1998, pp. 261-263). For individual graduates, the plan guided their occupational choices and helped internalize their belief in the state's job allocation plan via political mobilization and propaganda.

\subsection{Being Selected into Party and Government Systems:} Four Modernizations and 'Reds and Experts'

In the People's Republic of China's first 30 years, the newly established regime produced a large number of highly educated and technically trained experts through the expansion of education and placed them in related professional positions under the centralized graduate job allocation plan. In terms of career progression, for technocrats in provincial leadership in the 1990s, $72.12 \%$ began to assume political positions during the period of $1980-1985$, about 20 to 30 years after graduating from college. Why and how did these technical experts move away from professional career lines and hold power in the party and government systems? At first glance, socioeconomic development helps to explain the rising demands for technical experts and the regime's reliance upon them for industrialization and modernization programs. But that is an insufficient explanation for the high number of career transitions from professional occupations to elite positions within a tightly controlled and fiercely competitive hierarchy. The following paragraphs will examine the supply and demand for cadres in the 1980 s by analyzing the historic convergence of the retirement of revolutionaries and the cadre policy of the Four Modernizations. A complementary perspective will be described to explain the emergence of technocrats in the 1980 s and their rise in the 1990s. It is closely related to the political impetus and considerations of reds and experts for paramount leaders in a new era of politics and policies.

After the chaotic years of the Cultural Revolution, the revolutionary veterans were rehabilitated and seized political power. They managed to regain legitimacy and popular confidence in the Chinese Communist Party and to restructure the nation's socioeconomic and political systems by adopting pragmatic and incremental reform strategies. One of the formidable problems that bothered these born-again reformers was the death and poor health of the aging revolutionary veterans. As indicated by Cheng Li and Lynn White (2003, p. 566), the average age was 64.6 for the 11th CC members and 62 for the 12 th CC members. The average age was 73.8 for members of the 12th Politburo Standing Committee and 71.8 for the 12th Politburo members. From the very outset of the reform, Deng Xiaoping and Chen Yun mentioned on different occasions that old revolutionaries were illsuited for the new tasks of economic development due to aging. In 1977, in a meeting with vice-ministeriallevel leaders from the party, government, and military systems, Deng openly doubted whether half of them were able to work in the office for eight hours every day. While he pointed out their vast revolutionary and work experiences, he counseled that they should be acutely aware of their lack of energy. In the report of Promoting and Training Young and Middle-Age Cadres is the Top Priority (tiba peiyang zhongqingnian ganbu shi dangwuzhiji，提拔培养中青年干部是当务之急) in May 
1981, Chen Yun (1981a) indicated the following observations about the age structure of leaders. Like the leading cadres of ministries, the top leaders at the provincial, municipal, and prefectural Chinese Communist Party were largely over 60 , and a large number of cadres were over 70. They were positioned high in the power hierarchy and burdened with heavy workloads. These senior leaders were ill-equipped to meet the demanding and sophisticated task of running a modern state. They could not afford to work hard for a prolonged period of time. A substantial number of them kept working in spite of illness and eventually died from overwork. In July 1981, Chen Yun (1981b) focused on the issue of power succession in terms of a shortage of eligible successors. He delivered the speech 'Promoting Thousands of Young and Middle-Aged Cadres' (chengqianshangwan de tiba zhongqingnian ganbu, 成千上万地提拔中青年干部). In addition, Deng Xiaoping and Chen Yun repeatedly emphasized the Chinese Communist Party's determination to eliminate 'three sorts of people' (san zhong ren, 三种人) from the cadre corps. In August 1980, Deng Xiaoping (1980) made an important speech, 'Reforming the Party-State Leadership System' (dang he guojia lingdao zhidu de gaige，党和国家领导制度的改革), and identified the 'three sorts of people' as the followers of the Gang of Four, those with the radical ideology of factionalism, and rebels. Deng stressed that they should be removed from office and excluded from Chinese power circles, as Chen Yun did in his 1981 speech.

On the eve of the sweeping post-Mao reforms, state leaders decided to recruit and promote young and middle-aged cadres in the context of large-scale socioeconomic and macropolitical transformations. The retirement of revolutionary veterans and the restructuring of cadre corps created a wide range of vacancies within the political hierarchies. At the same time, maintaining the regime's stability and accelerating modernization accentuated the need to co-opt highly trained specialists into the ruling elite. To bring young bloods into the party and bureaucracies, the state leaders overcame the structural barriers of cadre recruitment criteria and political resistance from revolutionaries by clarifying the issues of 'why,' 'who' and 'how,' to promote in cadre selection.

Promoting young cadres caused major concerns among revolutionaries' who had reasonable anxiety about their young successors' lack of experience. Deng Xiaoping and Chen Yun compared young cadres with revolutionary veterans and explained the regime's imperative to recruit cadres for three reasons. First, veteran cadres became mature and independent by extending their revolutionary and occupational experience particularly during their formative years. Likewise, young cadres were expected to acquire in-depth career experience from administrative practices and training. Second, both aging revolutionaries and young cadres seemed inexperienced in the face of the new tasks and obstacles arising from the modernization and reform processes. Both of them were vulnerable to failure. Third, young and middle-aged cadres were energetic and professional and possessed technical knowledge and expertise. More importantly, they largely came from the birth cohorts of the 1930s and the 1940s and had bitter memories of the Cultural Revolution: "As the Cultural Revolution grown-ups, they understand the views and behaviors of the youth in the early years of the Cultural Revolution" (Chen, 1981b, p. 300). Chen Yun (1981b, p. 299) declared:

At present, several veteran cadres are still irrational in promoting the younger generation and fail to recognize the urgent need for cadre selection. It would be detrimental to the Party if unqualified candidates were ultimately placed in leadership positions only after elder leaders cracked up.

Deng Xiaoping (1981, p. 384) also warned of the urgency of recruiting young and middle-aged cadres: "This is a strategic issue in determining the political fortune of the Party and current leaders. Another catastrophe following the Cultural Revolution would come if power succession was not completed in three or five years."

In deciding who to promote to authority positions, the state leaders emphasized political integrity and expertise. Their cadre policy initiative, the Four Modernizations, was enshrined in the Party Constitution in 1982. It aimed to select younger, politically reliable, well-educated, and technically professional cadres. A candidate for political promotion could be graduate of a vocational school or a college (dazhuan, 大专) in the postliberation era, technicians with over 10-year seniority in professional occupations, young and middle-aged cadres without college education but with deep practical experience, as well as sent-down youths and talents with self-learning skills. Deng Xiaoping (1980, p. 325) summed up the selection criteria of potentially qualified candidates: "The young and middle-aged cadres with political loyalty, diligence, and specialized knowledge are widely positioned in every walk of life. They spread across various localities and divisions. The central issue is that we have not discovered and promoted them."

In July 1981, Deng Xiaoping (1981, p. 386) made a brief comment on political reliability and meritocracy for college graduates in the 1960s while discussing how to rejuvenate the leadership: "They are relatively professional and capable. As college graduates several years before the Cultural Revolution, a vast majority of them are politically reliable. They are by and large 40 years old." He argued and provided a specific example of deputy director of the Second Automobile Factory, who completed his college education one or two years before the Cultural Revolution. He took the opposite position in radical ideology and policies and was suppressed shortly after the outbreak of the Cultural Revolution: "Suffering from suppression in the course of the Cultural Revolution is recognized as one of the political criteria," Deng (1981, p. 386) declared: 
Is he an expert? He has already assumed the leading post of deputy director in a large factory. Why could he not become an expert if receiving training in party schools and possessing more diverse career experience by holding other posts?

From a career perspective, technically-trained college graduates in the 1950s and the 1960s were turned into technical experts with lengthy professional work experience through the 1970s and the 1980s. Were they matched close enough to the cadre policy of the Four Modernizations so that they could constitute a pool of qualified candidates for political office during the massive leadership reshuffles of the reform era, turning out to be the technocrats of the 1990s?

For youthful rejuvenation, the average age for technocrats upon entry into public service was 39.65 in the 1990s. Among them, those aged under 30 accounted for $11.14 \%$, between 30 and 39, 30.48\%, between 40 and $49,52.19 \%$, and over $50,6.19 \%$. In terms of specialized knowledge and professional competency, they benefited from educational expansion and received the technical training of a full-time college education. They were allocated to professional occupations and stayed at the SOEs for over ten years under the state planning of manpower. $74.50 \%$ of them possessed professional titles such as engineer, economist, and the like. For $44.91 \%$ of the 1990s technocrats, their first job in the political system was closely related to their educational credentials and professional career experience.

For political reliability, $98.10 \%$ of the 1990 s technocrats joined the Chinese Communist Party. Of these Chinese Communist Party technocrats, $96.72 \%$ became Chinese Communist Party members before working in the party or government systems. In terms of the timing of joining the Chinese Communist Party, $41.17 \%$ were admitted to the Chinese Communist Party before the Cultural Revolution. With respect to the age of joining the Chinese Communist Party, $56.75 \%$ became Chinese Communist Party members between the ages 20 and 29. For the technocrats joining the Chinese Communist Party before beginning public service, the average Chinese Communist Party seniority was 12.99 years. 55.75\% had Chinese Communist Party seniority of over 10 years.

In addition to Chinese Communist Party membership and seniority, another salient criterion for political reliability was party work at SOEs, colleges, or research institutes. Empirically, 57.09\% of the 1990s technocrats took charge of party work before occupying political positions. For example, they concurrently worked as head of the SOE and party secretary. The average party work tenure was 7.92 years before entering public service. To be specific, the shortest tenure was five months and the longest tenure was 22 years. Looking at the typical career pattern, $50.90 \%$ of the 1990 s technocrats had a career pattern of party work with an average seniority of 24.78 years.
As a final note, political screening was required for every college application and job assignment in the 1950 s and the 1960s. Political screening focused on family origins, family members, individual class and political status, main social ties, rewards and penalties, investigation results, and so on. Documents related to that political screening were an important part of every graduate's dossier for job allocation purposes. In this respect, college graduates working at the SOEs were politically reliable because they had already been vigorously screened.

In summary, this analysis of educational backgrounds, professional occupations, party membership, and party work experience provides a compelling explanation for why technical specialists working in the 1970s and the 1980 s fit the recruitment criteria under the cadre policy of Four the Modernizations and subsequently steered their careers to party and administrative systems and political power. From this perspective, it is possible to see why they could be regarded as both Red and expert and therefore eligible or even ideal candidates for authority positions when state leaders reached a consensus about promoting young and middle-aged cadres in the 1980s.

\section{Conclusions}

This article presented an analytical account of China's provincial leadership transformation. It focused on the rise of technocrats in the 1990s and examined their major life transitions. Career transitions included admission to university, moving from college to work, and then to jobs in the party or in administrative posts. It also mapped out the interactions among individual career opportunities, the composition of the group, and the shifts in state policy that directly affected them. For technocrats in the 1990s, their educational and career opportunities were significantly shaped by macrosociopolitical transformation, such as the expansion of education, faculty restructuring, the graduate job allocation plan which started in the 1950s, and the retirement of revolutionary veterans in the 1970s and the 1980s. In short, they were the right people, in the right place, at the right time. The party state sought to co-opt these technical experts into the power hierarchy in order to legitimize its rule by fostering economic and technological development. More importantly for purposes of this study, the party state sought to maintain a delicate balance between cadre selection criteria and the pool of viable political candidates who were educated and worked within the existing career mobility structure.

For those reasons, this study's analyses support the political technocracy theory: There was an alliance of technocrats and career bureaucrats. The emergence of technocratic leadership does not necessarily represent a preference for technical expertise over political loyalty in cadre selection.

As observed in this study, technocrats in the 1990s were thoroughly Red and deeply expert per se, possessing both educational and political credentials. This empir- 
ical evidence supports Zang's argument. That is, despite a political alliance between bureaucrats and technocrats, party bureaucrats only recruited "the technocrats who express loyalty to the regime and the orthodox ideology" (Zang, 1993, pp. 802-803). However, the ascent of technocrats in the 1990s by no means signaled the replacement of generalists with specialists in Chinese politics. Technocrats cooperated with career bureaucrats and had a slight advantage in terms of numbers in the 1990s. For that reason, technocrats appeared to be the backbone of Chinese provincial leadership even though career bureaucrats still sat at the apex of the power hierarchy. After 2000, career bureaucrats came back to prominence as the percentage of technocrats decreased. With the incremental institutionalization of cadre recruitment and promotion, particularly the emphasis on stepby-step promotion, generalists were positioned advantageously in very fierce political competition because they got acquainted with the functioning and operation of party and bureaucratic systems and possessed managerial and coordinated competency as well as diverse administrative practices.

As the regime's agenda was shifted to economic development, industrialization, and modernization, the demand for technical specialists became greater. However, this was an insufficient condition for technocratic dominance. Technocrats did not come to prominence in the 1950 s when the party state promoted socialist reconstruction and Communist-style industrialization. And, they did not come to prominence the early years of the 21st century when the party state launched its growth strategy of innovation nation and the number of college students studying science, technology, engineering, and mathematics increased dramatically.

This article argues that turning technically trained experts into technocrats was the political choice of reformers, but this choice was significantly conditioned by the supply of cadre candidates. As to the cadre corps before the Cultural Revolution, old revolutionaries passed away or retired to the second line. For the cadre corps after the Cultural Revolution, the 'three sorts of people' stepped down from political office and unqualified cadres were transferred outside the party systems and government bureaucracies. Additionally, the general population was poorly educated, particularly when educational institutions and training systems were largely paralyzed due to the ten-year period of chaos during the Cultural Revolution. In this historical context, the pool of potential cadres inside or outside the political system was extremely limited.

At the same time, the basis of legitimacy for running a modern state changed. The supreme leaders shifted cadre recruitment to consider both political reliability and such meritocratic standards as education and professional competency. By considering the supply and demand of prospective cadres, they had no choice but to expand the source and scope of cadre selection along the new recruitment criteria. They had to turn to can- didates who graduated before the Cultural Revolution. Educational reform before the Cultural Revolution produced a large number of technically trained college graduates. Under the graduate job allocation plan, they were assigned to technical positions at SOEs and accumulated professional career experience. They largely escaped the Cultural Revolution's political purges and repression. Their career opportunities for transfers and advancement arose because they were politically loyal, highly educated, and professionally competent. It is not the specialty of science and engineering vis-à-vis humanities and social sciences that conferred significant competitive advantage on the technical specialists. The underlying force of co-opting technical specialists into the ruling elite was a dilemma between the imperative of youthful rejuvenation and the lack of politically reliable and well-educated cadres at the critical juncture of a personnel reshuffle. As the cadres, and the public in general, have become more educated, personnel bottlenecks have been resolved and technical experts are no longer considered a major source of cadres. As for China, the short-term emergence of technocratic leadership is peculiar to the early years of the post-Cultural Revolution era, spanning from the late 1970s through the 1990s. This data does not suggest that technocrats have grown into a strongly competitive and cohesive political force with a shared ideology and group identity. Nor does it mean that China is taking the technocratic road.

Drawing upon data about a group of technocrats in provincial leadership in the 1990s, this article has provided an important lens through which a link among individuals' career transitions and socioeconomic and macropolitical transformations can be understood. In explaining the rise of the 1990s technocrats, this article has directed attention away from the influence of socioeconomic factors to the impact of state policies as well as the political preferences, impetus, and constraints in the cadre selection process. The rise of the 1990s technocrats was not an isolated phenomenon or peculiar to China. It also occurred in the Soviet Union, Eastern Europe, Mexico, Chile, Taiwan, and other countries. Comparative studies would provide interesting observations and convincing explanations for this seemingly common technocratic turn.

\section{Acknowledgments}

This research is supported by the projects of "Historical Transitions in the Promotion Dynamics for Chinese Political Elites since the Founding of the P.R.C." (16CSH004) and "The Incentive Mechanism for Motivating Cadres' Accountability and Performance in the New Era" (20ZDA024) from the National Social Science Fund of China.

\section{Conflict of Interests}

The author declares no conflict of interests. 


\section{References}

Agelasto, M. (1998). Graduate employment: From manpower planning to the market economy. In M. Agelasto \& B. Adamson (Eds.), Higher education in postMao China (pp. 259-280). Hong Kong: Hong Kong University Press.

Andreas, J. (2009). Rise of the red engineers: The Cultural Revolution and the origins of China's new class. Stanford, CA: Stanford University Press.

Bo, Z. Y. (2002). Chinese provincial leaders: Economic performance and political mobility since 1949. New York, NY: M. E. Sharpe, Inc.

Bo, Z. Y. (2008). The seventeenth Central Committee of the Chinese Communist Party: Institutional representation. Issues \& Studies, 44(3), 1-41.

Chen, Y. (1981a). Tiba peiyang zhongqingnian ganbu shi dangwuzhiji [Promoting and training young and middle-age cadres is the top priority]. In Selected works of Chen Yun (Vol. 3, pp. 292-297). Beijing: People's Publishing House.

Chen, Y. (1981b). Chengqianshangwan de tiba zhongqingnian ganbu [Promoting thousands of young and middle-aged cadres). In Selected works of Chen Yun (Vol. 3, pp. 298-303). Beijing: People's Publishing House.

Deng, X. P. (1980). Dang he guojia lingdao zhidu de gaige [Reforming the party-state leadership system]. In Selected works of Deng Xiaoping (Vol. 2, pp. 320-343). Beijing: People's Publishing House.

Deng, X. P. (1981). Laoganbu diyiwei de renwu shi xuanba zhongqingnian ganbu [Selecting young and middleaged cadres is the first priority task for veteran cadres]. In Selected Works of Deng Xiaoping (Vol. 2, 384-388). Beijing: People's Publishing House.

Feng, J. Q. (2010). Zhongxian ganbu [Cadres from Zhong county] (Unpublished doctoral dissertation). Peking University, Beijing, China.

Goodman, D. S. G. (1980). The provincial first party secretary in the People's Republic of China, 1949-78: A profile. British Journal of Political Science, 10(1), 39-74.

Landry, P. F. (2003). The political management of mayors in post-Deng China. The Copenhagen Journal of Asian Studies, 17, 31-58.

Lee, $H$.Y. (1983). China's $12^{\text {th }}$ central committee: Rehabilitated cadres and technocrats. Asian Survey, 23(6), 673-691.
Lee, H. Y. (1991). From revolutionary cadres to party technocrats in Socialist China. Berkeley, CA: University of California Press.

Li, C. (2002). China's leaders: The new generations. Lanham, MD: Rowman \& Littlefield Publishers, Inc.

Li, C., \& Bachman, D. (1989). Localism, elitism, and immobilism: Elite formation and social change in post-Mao China. World Politics, 42(1), 64-94.

Li, C., \& White, L. (1988). The thirteenth central committee of the Chinese Communist Party: From mobilizers to managers. Asian Survey, 28(4), 371-399.

Li, C., \& White, L. (1990). Elite transformation and modern change in mainland China and Taiwan: Empirical data and the theory of technocracy. The China Quarterly, 121, 1-35.

Li, C., \& White, L. (1998). The fifteenth central committee of the Chinese Communist Party: Full-fledged technocratic leadership with partial control by Jiang Zemin. Asian Survey, 38(3), 231-264.

Li, C., \& White, L. (2003). The $16^{\text {th }}$ central committee of the Chinese Communist Party: Hu gets what? Asian Survey, 43, 553-597.

Lin, R. R. (2017). The educational attainment of Chinese provincial leaders in reforming China, 1990-2013: A longitudinal examination. China: An International Journal, 15(3), 100-127.

Lin, T. J. (2012). The promotion logic of prefecture-level mayors in China. China: An International Journal, 10(3), 86-109.

Xu, X. L. (2001). Houmao shidai de jingying zhuanhuan he yifuxing jishu guanliao de xingqi [Elite transformation and the rise of technocratic cadres in post-Mao China]. Strategy and Management, 6, 65-76.

Zang, X. W. (1991). Provincial elite in post-Mao China. Asian Survey, 31(6), 512-525.

Zang, X. W. (1993). The fourteenth central committee of the Chinese Communist Party: Technocracy or political technocracy? Asian Survey, 33(8), 787-803.

Zang, X. W. (1999). The consolidation of political technocracy in China: The fourteenth and fifteenth central committees of the Chinese Communist Party. Journal of Communist Studies and Transition Politics, 15(3), 101-113.

Zhou, E. L. (1950). Zai quanguo gaodeng jiaoyu huiyi shang de jianghua [Speech on the national higher education conference]. In Selected works of Zhou Enlai (Vol. 2, pp. 15-20). Beijing: People's Publishing House.

\section{About the Author}

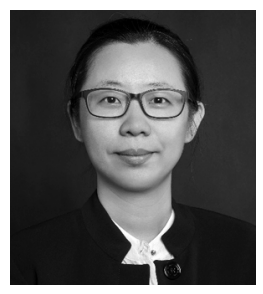

Rongrong Lin is an Associate Research Fellow of Research Center of CPC Rules and Regulations, Institute of Urban Governance, Shenzhen University, People's Republic of China. She obtained her PhD from the School of East Asian Studies at the University of Sheffield, UK. Her research interests include elite politics and public personnel management. Recent publications are "The Educational Attainment of Chinese Provincial Leaders in Reforming China, 1990-2013: A Longitudinal Examination" (China: An International Journal) and "How Does Human Capital Affect Cadre Promotion?" (CASS Journal of Political Science). 